\title{
Influence of soil on the efficacy of entomopathogenic nematodes in reducing Diabrotica virgifera virgifera in maize
}

\author{
Stefan Toepfer $\cdot$ Benedikt Kurtz $\cdot$ Ulrich Kuhlmann
}

Received: 28 August 2009/Accepted: 18 January 2010/Published online: 27 February 2010

(C) The Author(s) 2010. This article is published with open access at Springerlink.com

\begin{abstract}
The use of entomopathogenic nematodes is one potential non-chemical approach to control the larvae of the invasive western corn rootworm (Diabrotica virgifera virgifera LeConte, Coleoptera: Chrysomelidae) in Europe. This study investigated the efficacy of Heterorhabditis bacteriophora Poinar (Rhabditida: Heterorhabditidae), Heterorhabditis megidis Poinar, Jackson and Klein (Rh., Heterorhabditidae) and Steinernema feltiae Filipjev (Rh., Steinernematidae) in reducing $D$. v. virgifera as a function of soil characteristics. A field experiment was repeated four times in southern Hungary using artificially infested maize plants potted into three different soils. Sleeve gauze cages were used to assess the number of emerging adult $D$. $v$. virgifera from the treatments and untreated controls. Results indicate that nematodes have the potential to reduce $D$. v. virgifera larvae in most soils; however, their efficacy can be higher in maize fields with heavy clay or silty clay soils than in sandy soils, which is in contrast to the common assumption that nematodes perform better in sandy soils than in heavy soils.
\end{abstract}

Communicated by R.-U. Ehlers.

S. Toepfer

CABI Europe, c/o Directorate for Plant Protection and Soil Conservation, Rarosi ut 110, 6800 Hodmezovasarhely, Hungary

e-mail: s.toepfer@cabi.org

S. Toepfer · B. Kurtz · U. Kuhlmann $(\bowtie)$

CABI Europe-Switzerland, Rue des Grillons 1,

2800 Delémont, Switzerland

e-mail: U.Kuhlmann@cabi.org

B. Kurtz

Department for Crop Sciences, University of Goettingen,

Grisebachstrasse 6, 37077 Goettingen, Germany
Keywords Western corn rootworm .

Heterorhabditis bacteriophora - Heterorhabditis megidis . Steinernema feltiae - Inundative biological control .

Soil texture $\cdot$ Zea mays

\section{Introduction}

The western corn rootworm, Diabrotica virgifera ssp. virgifera LeConte (Coleoptera: Chrysomelidae) is a widespread and serious pest of maize, Zea mays (L.). Believed to have originated in Mexico, it spread throughout parts of the United States and Canada during the twentieth century as maize production increased (Krysan and Smith 1986; Levine and Oloumi 1991). Then, over the last two decades, there were repeated accidental introductions of D. v. virgifera from North America into Europe (Miller et al. 2005). The pest is now an economic threat to maize production in many European countries, namely Austria, Hungary, Italy, Romania, Slovakia, Ukraine and Serbia (Sivcev and Tomasev 2002; Kiss et al. 2005).

Diabrotica $v$. virgifera is a univoltine species whose three larval instars feed almost exclusively on maize roots (Moeser and Vidal 2005). The feeding damage can cause plant lodging and significant yield losses. To control this pest, European farmers typically apply granular soil insecticides or insecticide-coated seeds against the larvae and foliar insecticides against the adults (Ward et al. 2004). The use of chemical pesticides in maize, however, can interfere with effective integrated pest management and biological control programmes that have been established for other European maize pests (Babendreier et al. 2006). Moreover, soil insecticides and insecticide-coated seeds can, when improperly applied, endanger honeybees (Heimbach et al. 2008; Pistorius and Bischoff 2008). Thus, 
Kuhlmann and Burgt (1998) and Babendreier et al. (2006) stressed the importance of biological control options.

For a pest like $D$. v. virgifera, whose most damaging stages are below-ground, soil-dwelling entomopathogenic nematodes are considered strong candidates for use in a biological control programme. Several field studies (e.g., Creighton and Fassuliotis 1985; Poinar et al. 1983; Kaya et al. 1989; Thurston and Yule 1990; Ellsbury et al. 1996; Jackson 1997) have shown variable efficacy of nematodes in controlling Diabrotica pests and have revealed a number of factors that may reduce their impact. Failed control attempts using nematodes have been attributed to (i) the use of nematode species or strains that were not adapted to the host or to local conditions (Jackson 1995; Georgis et al. 2006), (ii) a lack of alternative hosts in the soil (Brust 1991; Susurluk 2005), (iii) losses during application (Smits et al. 1994; Cabanillas et al. 2005) or, of particular interest in the current study, (iv) unfavourable soil characteristics (Kaya 1990; Koppenhöfer and Fuzy 2006a, b).

The activity, infectivity and survival of entomopathogenic nematodes can be profoundly influenced by soil composition, through its effects on moisture retention (Ellsbury et al. 1996), oxygen supply (Kaya 1990; Koppenhoefer and Fuzy 2006b) and texture (Kaya 1990). For example, survival of Steinernema glaseri Steiner and S. carpocapsae (Weiser) (both Rhabditida: Steinernematidae) was found to be lowest in clay soils followed by silty clay and sand or sandy silt (Kung et al. 1990). Heterorhabditis bacteriophora Poinar (Rhabditida: Heterorhabditidae) was reported to move least in clay soil and most in fine sand or sandy silt soils (Barbercheck and Wang 1997). Kurtz et al. (2008) showed in laboratory bioassays that H. bacteriophora, H. megidis Poinar, Jackson and Klein (Rh., Heterorhabditidae) and Steinernema feltiae Filipjev (Rh.: Steinernematidae) were more effective in killing third instar $D$. v. virgifera larvae in sand than in non-sandy garden soil. Therefore, one could assume that $D$. $v$. virgifera larvae would be better controlled by nematodes in maize fields with sandy soils than in fields with heavy clay or silty soils. This, in turn, would largely reduce the potential market areas for a nematode-based biological control product.

In contrast to the high performance of nematodes observed in sandy soil, $D$. v. virgifera larval survival is reported to be lowest in such soils with high sand content (Turpin and Peters 1971; MacDonald and Ellis 1990) and economic root damage or plant lodging is more frequently reported from regions with heavy clay soils than from those with light sandy soils (I. Zseller, 2005, personal communication). Consequently, we might hypothesize nematodes to be unsuitable for the biological control of $D$. v. virgifera larvae in dense soils.

In this study, we examined the impact of soil characteristics on the efficacy of entomopathogenic nematode species that had (a) proved virulent to $D$. v. virgifera larvae in laboratory screenings (Toepfer et al. 2005) and (b) had been successfully applied as a fluid during sowing of maize or during mechanical weed control in field experiments (Toepfer et al. 2008). The nematodes were applied to $D$. v. virgifera-infested maize pots with soils of three different compositions of clay, silt and sand. The efficacy of each nematode in controlling $D$. v. virgifera in these soils was assessed by counting the emerging $D$. $v$. virgifera adults in sleeve cages placed around the plants. The results of this study are a prerequisite to assess the potential market areas for a nematode-based biological control product against this invasive maize pest, prior to starting the development and implementation of such a product.

\section{Materials and methods}

Experimental setup and soil characteristics

Three entomopathogenic nematode species were applied against $D$. $v$. virgifera larvae in a field experiment using artificially infested maize plants potted into three different soils, referred to as soils A, B, C (Table 1). Those soils were prepared by adding different amounts of river sand (nearby river Tisza) to three batches of air dried natural gleyic Csernozem soil (IUSS 2007) of silty clay texture taken from the experimental field (Table 1). Soil and sand had been sieved through a $5-\mathrm{cm}$ mesh in order to remove large pieces, prior mixing with a shovel. Five 1-1 soil samples were randomly taken from each of the three prepared soil groups in order to analyse soil texture (Atterberg $1905)$ and $\mathrm{pH}\left(\mathrm{H}_{2} \mathrm{O}\right)$ (Table 1). Soil moisture was measured as w\%(=grav.\%) at 50-100-mm depth in two pots per soil type every 10 min (Hotdog DT1, Elpro, Switzerland). Soil temperature was measured at $100-150-\mathrm{mm}$ depth in two pots per soil type every hour (Hobo data loggers, Onset Computer, Bourne, MA, USA). Soil texture, $\mathrm{pH}$, moisture and temperature were compared between soil types using the non-parametric M. Whitney $U$ test (Table 1).

Maize plants of the hybrid Magister (UFA Semences, Bussigny, Switzerland) were grown in plastic pots $(d=$ $200 \mathrm{~mm}, h=220 \mathrm{~mm}$ ). Two fungicide-treated maize grains (fungicide Fludioxonil and Metalaxyl-M, Maxim XL 035FS, Syngenta) were sowed into each pot and, if both germinated, one plant was removed. Pots were placed into the rows of a maize field with the top of the pots at the level of the soil surface always leaving at least one maize plant as a buffer between pots (systematic block design). At the 4-6 leaf stage of maize, potted plants were infested with eight second instar D. v. virgifera larvae (see below). One week later, nematodes were applied (see below and Table 2). The roots of the hybrid Magister emit the 
Table 1 Characteristics of the three soils of different sand content used for growing maize in pots for four plant-scale field experiments in Csongrad county, southern Hungary in 2005 and 2006 (N 46 25' 59.54"; E 20 20 22.12" ; 83 m elevation)

\begin{tabular}{|c|c|c|c|}
\hline Soil characteristics & Soil A & Soil B & Soil C \\
\hline Sand content $(\%)$ & $14^{\mathrm{a}}$ & $47^{\mathrm{b}}$ & $63^{\mathrm{c}}$ \\
\hline Silt content $(\%)$ & $44^{\mathrm{b}}$ & $17^{\mathrm{a}}$ & $16^{\mathrm{a}}$ \\
\hline Clay content $(\%)$ & $42^{\mathrm{c}}$ & $36^{\mathrm{b}}$ & $21^{\mathrm{a}}$ \\
\hline $\mathrm{PH}\left(\mathrm{H}_{2} \mathrm{O}\right)$ & $8.3^{\mathrm{a}}$ & $8.2^{\mathrm{a}}$ & $8.7^{\mathrm{a}}$ \\
\hline Humus $(\%)$ & $2-4^{\mathrm{a}}$ & $2-3^{a}$ & $1-3^{\mathrm{a}}$ \\
\hline Soil moisture at $50-100-\mathrm{mm}$ depth $(\mathrm{w} \%=$ grav.\%) & $24^{\mathrm{b}}$ & $23^{\mathrm{b}}$ & $19^{\mathrm{a}}$ \\
\hline Mean soil temperature $\left({ }^{\circ} \mathrm{C}\right)$ at $100-150-\mathrm{mm}$ depth & $19.4^{\mathrm{a}}$ & $19.1^{\mathrm{a}}$ & $18.7^{\mathrm{a}}$ \\
\hline Min soil temperature $\left({ }^{\circ} \mathrm{C}\right)$ at $100-150-\mathrm{mm}$ depth & $13.3^{\mathrm{a}}$ & $13.8^{\mathrm{a}}$ & $14.1^{\mathrm{a}}$ \\
\hline Max soil temperature $\left({ }^{\circ} \mathrm{C}\right)$ at $100-150-\mathrm{mm}$ depth & $29.4^{\mathrm{a}}$ & $29.5^{\mathrm{a}}$ & $29.8^{\mathrm{a}}$ \\
\hline
\end{tabular}

Soils were prepared by adding different amounts of river sand to natural gleyic Csernozem soil of silty clay texture (soil A) taken from the experimental field. The average soil moisture from May to June 2006 is shown as well as the average soil temperature from August to September 2006; letters beside values indicate significant differences between soils according to the non-parametric M Whitney $U$ test at $P<0.05$

nematode-attracting volatile $\beta$-caryophyllene in response to D. v. virgifera larval feeding (Rasmann et al. 2005). Eleven to twenty-two replicates were organised for each treatment group (soil type and nematode species) and for the controls (Table 2). At the 6-8 leaf stage of maize (see dates in Table 2), gauze sleeve cages (approximately $1.5-\mathrm{m}$ height) were placed over the potted and D. v. virgiferainfested plants in order to capture emerging adults. The experiment was repeated four times.

\section{Diabrotica $v$. virgifera source and infestation of maize}

Diabrotica $v$. virgifera eggs were obtained from a laboratory culture of field-collected beetles in southern Hungary $\left(25^{\circ} \mathrm{C}\right.$ day, $15-20^{\circ} \mathrm{C}$ night, 14L:10D, 40-60\% r.h.; for procedures see Singh and Moore 1985). The eggs were overwintered at $6-8^{\circ} \mathrm{C}$ in moist sand, and diapause was broken in early April by transferring them to $25^{\circ} \mathrm{C}$ for 14 days. Approximately 200-300 maize grains of the hybrid Magister were washed with soap to remove fungicides and planted in a plastic tray $(300 \times 450 \mathrm{~mm})$ with moist potting soil (Garri Plusz, Garri Company, Budapest, Hungary). Five days after planting, ready-to-hatch eggs were placed into these plastic trays, which were then stored in the dark at $25^{\circ} \mathrm{C}$ (approximately
5,000 eggs per tray). One week after larval hatching (when most larvae were in late first instar stage), the soil containing the larvae was put onto a new tray with new maize plants to provide more food for further larval development. After another week, late second instars were obtained by manually crumbling the soil and maize roots. Using a moist paintbrush, larvae were transferred into several Petri dishes (45-mm diameter) containing a small amount of soil and then taken to the field. The potted maize plants were infested with eight $D$. v. virgifera larvae by emptying the contents of the Petri dishes (larvae and soil) into two 100-140-mm deep holes in the soil at a distance of 50-80 $\mathrm{mm}$ from both sides of the maize plant. About 8-10 third-instar larvae per plant root are often estimated to cause economic damage to a plant, depending on local conditions and maize prices (C. R. Edwards, personal communication, 2004); occasionally already two larvae per plant are considered sufficient (Reed et al. 1991).

Nematode sources and application

Infective juveniles of three nematode species were used in this study: (1) a hybrid of European and US strains of $H$. bacteriophora Poinar provided from liquid culture by

Table 2 Experimental time table for applying three nematode species against D. v. virgifera larvae into three different soils of potted maize plants in Csongrad county, southern Hungary in 2005 and 2006

\begin{tabular}{lllll}
\hline Experiment & Dates & & \\
\cline { 2 - 5 } & Infestation with 8 & Nematode application & D. v. virgifera adult emergence \\
D. v. virgifera larvae & & & \\
\hline 1 & Early Sept 2005 & Mid Sept 2005 & Early Oct-late Oct 2005 & $19-22$ \\
2 & 4 May 06 & 15 May 2006 & Late May-early July 2006 & $11-13$ \\
3 & 30 May 06 & 8 June 2006 & Mid June-mid July 2006 & $17-19$ \\
4 & 15 Mid Aug 2006 & 22 Aug 2006 & Early Sept-mid Oct 2006 & $11-13$ \\
\hline
\end{tabular}

$n=$ number of plants (=pots) assessed per treatment group (soil type and nematode species) and control 
e-nema GmbH, Schwentinental, Germany, (2) the Dutch NL-HW79 strain of H. megidis Poinar, Jackson and Klein re-isolated from Swiss soils and provided from a liquid culture by Andermatt Biocontrol, Grossdietwil, Switzerland, and (3) a hybrid of European strains of S. feltiae (Filipjev) provided from liquid culture by e-nema $\mathrm{GmbH}$. These nematodes were known to be effective against second and third instars from previous laboratory bioassays (70-100\% mortality; Rasmann et al. 2005; Toepfer et al. 2005). Heterorhabditis bacteriophora and S. feltiae were shipped in clay in a cool box from the producer to the experimental site, and H. megidis was shipped in vermiculite. All nematodes were stored in their shipping material at $7-9^{\circ} \mathrm{C}$ in darkness until use. Approximately $2-3 \mathrm{~h}$ before application, the infective juveniles were diluted with the carrier material in tap water to the required concentration. Using a pipette, 2,000 infective juveniles in 1.2-2-ml tap water were injected twice (in the late evening and following morning) $100 \mathrm{~mm}$ into the soil at distances of $150 \mathrm{~mm}$ from the plant, totalling 4,000 juveniles per pot $(=13$ juveniles per $\mathrm{cm}^{2}$ or $1.3 \times 10^{9}$ juveniles per hectare). These injections simulated the commonly practised application of nematodes as a fluid into soil during sowing of maize or during mechanical weed control (Toepfer et al. 2008, 2010).

To evaluate the quality of each of the nematode shipments prior to application (Kaya and Stock 1997), 100 infective juveniles were added to three plastic cups ( $d=40 \mathrm{~mm}, h=60 \mathrm{~mm}$ ) containing $200 \mathrm{~g}$ of moist, sterilised sand and five larvae of Galleria mellonella L. (Lepidoptera: Pyralidae). Mortality of G. mellonella larvae was assessed after 1 week in darkness and at $22^{\circ} \mathrm{C}$. Mortality of $70-100 \%$ of $G$. mellonella was found for all nematode batches, indicating that the test material was of sufficient quality for subsequent applications and analyses.

\section{Data analyses}

Emerged adults were removed weekly from the sleeve cages during their period of emergence (Table 2) and counted. Emergence of adults was compared among soils, nematode species and controls in each experiment (Fig. 1) using the non-parametric M. Whitney $U$ test. In order to pool data from the four experimental repetitions, the mean weighted efficacy of each nematode species in each of the three soils was then calculated as the reduction of $D . v$. virgifera relative to the untreated controls (corrected efficacy $\%=(100-$ (beetles in treated pots $\times 100 /$ beetles in the control)) (Fig. 2). A comparison among efficacies of nematode species in the three different soils was conducted using the Bonferroni post hoc test following an ANOVA (Kinnear and Gray 2000).

The influence of soil characteristics on nematode efficacy in reducing $D$. v. virgifera was tested with between- subjects ANOVA (GLM procedure) in cases where a certain soil characteristic was proven significantly different between the soil types according the M Whitney $U$ test (see Table 1). Linear associations between soil characteristics and nematode efficacy were determined by the Pearson correlation coefficient after visually consulting scatter plots for linearity (Kinnear and Gray 2000).

\section{Results}

In most experiments nematodes reduced $D$. v. virgifera larvae, regardless of the soil they were applied to (Fig. 1). None of the three nematode species consistently reduced $D$. $v$. virgifera, i.e. $H$. bacteriophora reduced $D$. v. virgifera in eight out of eleven cases, and H. megidis and S. feltiae, each reduced $D . v$. virgifera in five out of 11 cases. Soil type generally influenced the efficacy of nematodes in the reduction of $D$. v. virgifera (one-way ANOVA: $\left.F_{(2,717)}=13.4, P<0.001\right)$.

Heterorhabditis bacteriophora and H. megidis were nearly double as effective in soil A as in soil B or C (soil A being the soil with the lowest sand and highest silt and clay content) (Fig. 2). In soil A, H. bacteriophora reduced D. v. virgifera by $58 \pm 33 \% \mathrm{SD}$, and $H$. megidis reduced D. v. virgifera by $33 \pm 37 \%$. No difference in the efficacy of both nematodes was found in soils B and C. Among the soil factors shown in Table 1, low sand content and high silt content were the factors best correlated with the efficacy of $H$. bacteriophora $(r=-0.311$ and 0.309 , both $P<0.001$; both had higher $r$ values than other factors). High silt content was the factor best correlated with the efficacy of $H$. megidis ( $r=0.23, P=0.001$ ).

Steinernema feltiae was most effective in soils A and B (Fig. 2), i.e. in soils with low or medium sand content. In those soils, S. feltiae reduced D. v. virgifera by $20 \pm 46 \%$ and $30 \pm 6 \%$, respectively. However, it rarely reduced D. v. virgifera in soil $\mathrm{C}$ with high sand content (Fig. 1). Among the soil factors shown in Table 1, high clay content was the factor best correlated with the efficacy of $S$. feltiae $(r=0.246, P=0.01)$.

The choice of a nematode species influenced the reduction of D. v. virgifera adult emergence (betweensubject ANOVA: $\left.F_{(11,717)}=23.8, P<0.001\right)$. Heteror habditis bacteriophora reduced D. v. virgifera by $33-58 \%$ on average across soils, which was significantly more than H. megidis (16-33\%) and S. feltiae (0-20\%) (Fig. 2).

Adult emergence of $D$. v. virgifera from untreated control pots varied among experiments and soils, i.e. between 0.08 and 1.8 emerging adults from the eight larvae used to infest each maize plant (Fig. 1). On average, $0.99 \pm 0.35$ adults emerged from soil $\mathrm{A}, 0.58 \pm 0.45$ from soil $\mathrm{B}$ and $0.88 \pm 0.47$ from soil C. Overall, high sand 
Fig. 1 Adult emergence from eight second instar $D$. v. virgifera larvae per maize plant from three different soils either treated with entomopathogenic nematodes or left untreated (potted maize plants in a maize field in southern Hungary; soils were prepared by adding different amounts of river sand to natural gleyic Csernozem soil of silty clay texture (soil A) taken from the experimental field; 11-22 potted maize plants were allocated to every treatment and control group in each of four experiment repetitions; error bars $=\mathrm{SEM}$; letters above bars indicate significant differences according to M Whitney $U$ test at $P<0.05)$
Experiment 1 (2005)

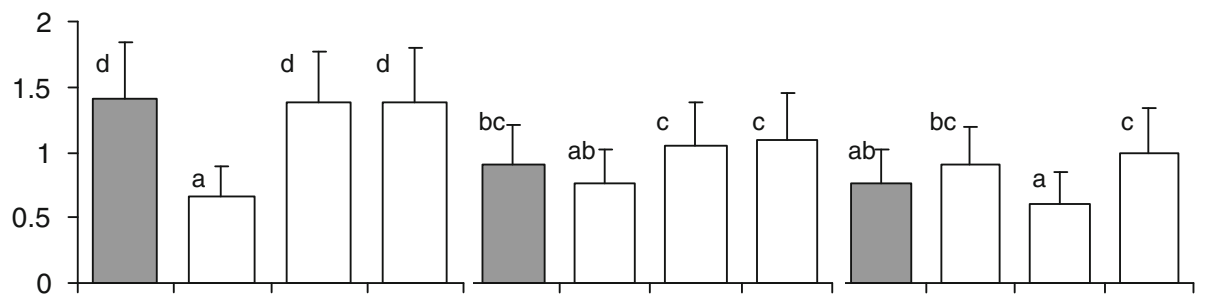

Experiment 2 (2006)

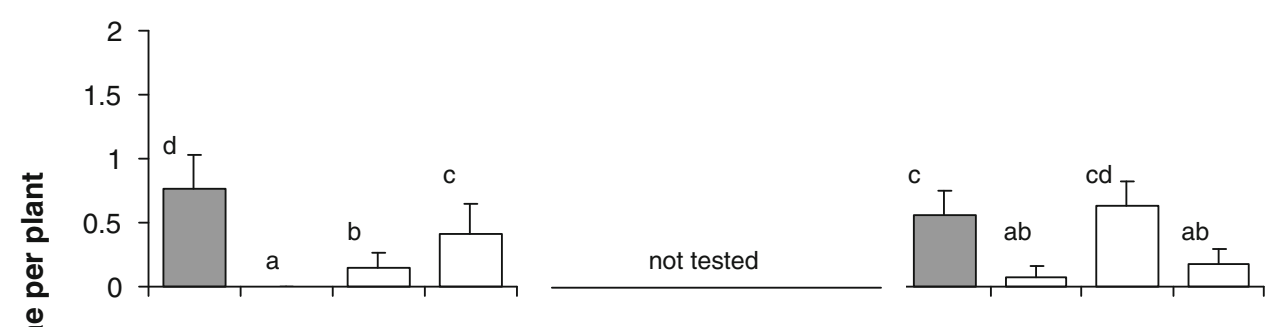

Experiment 3 (2006)

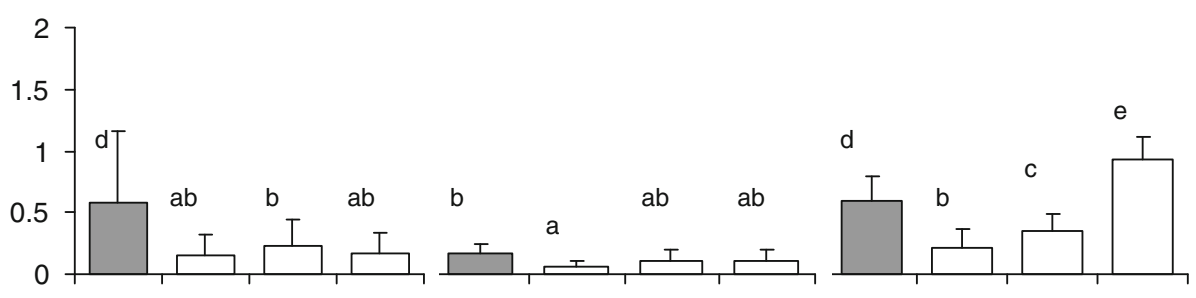

Experiment 4 (2006)

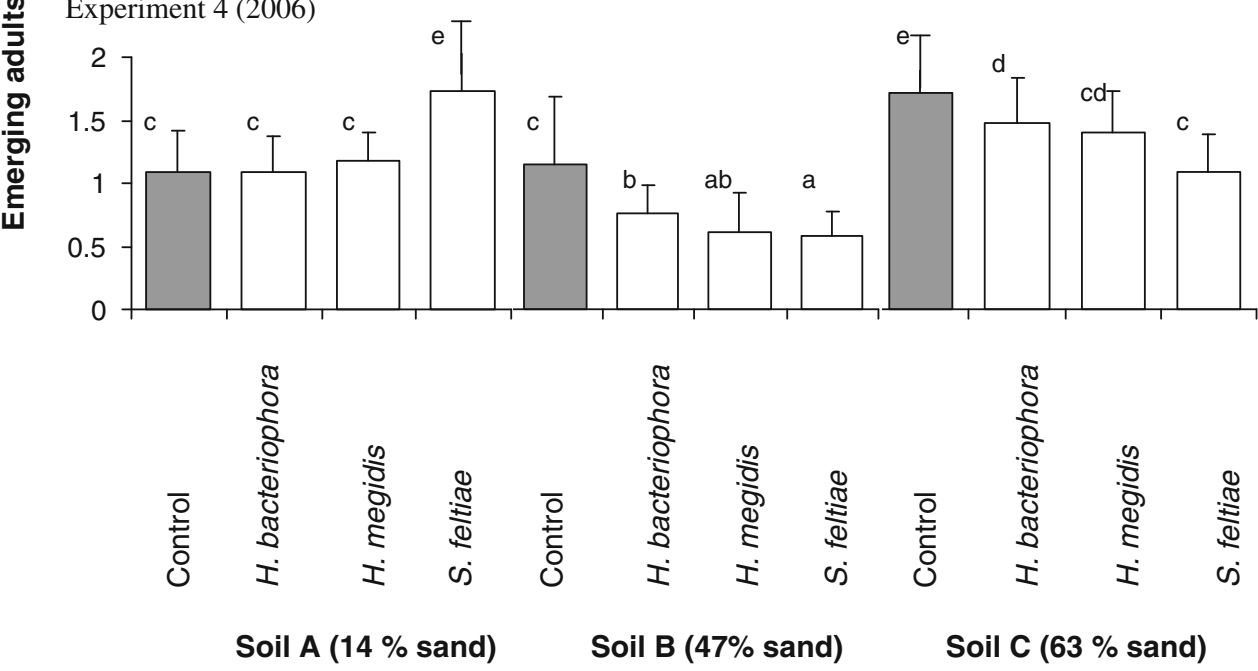

content influenced $D$. $v$. virgifera emergence negatively ( $r=-1.5, P=0.037$ ), whereas high silt content influenced $D$. $v$. virgifera emergence positively $(r=0.21$, $P=0.005)$.

\section{Discussion}

This study showed that nematodes can reduce $D$. v. virgifera emergence in all three of the soil types tested.
However, the higher efficacy in soils with high clay and silt content was surprising because several previous studies suggested that sandy soils provide good conditions for nematode survival, movement, host finding behaviour and infectivity (e.g., Kung et al. 1990; Barbercheck 1992). Our results suggest the opposite is true for $D$. $v$. virgifera control in maize fields. Only Barbercheck and Wang (1997) also found that $H$. bacteriophora killed more larvae of Diabrotica undecimpunctata Barber in loam than in sand. Our study does not provide much insight into which 


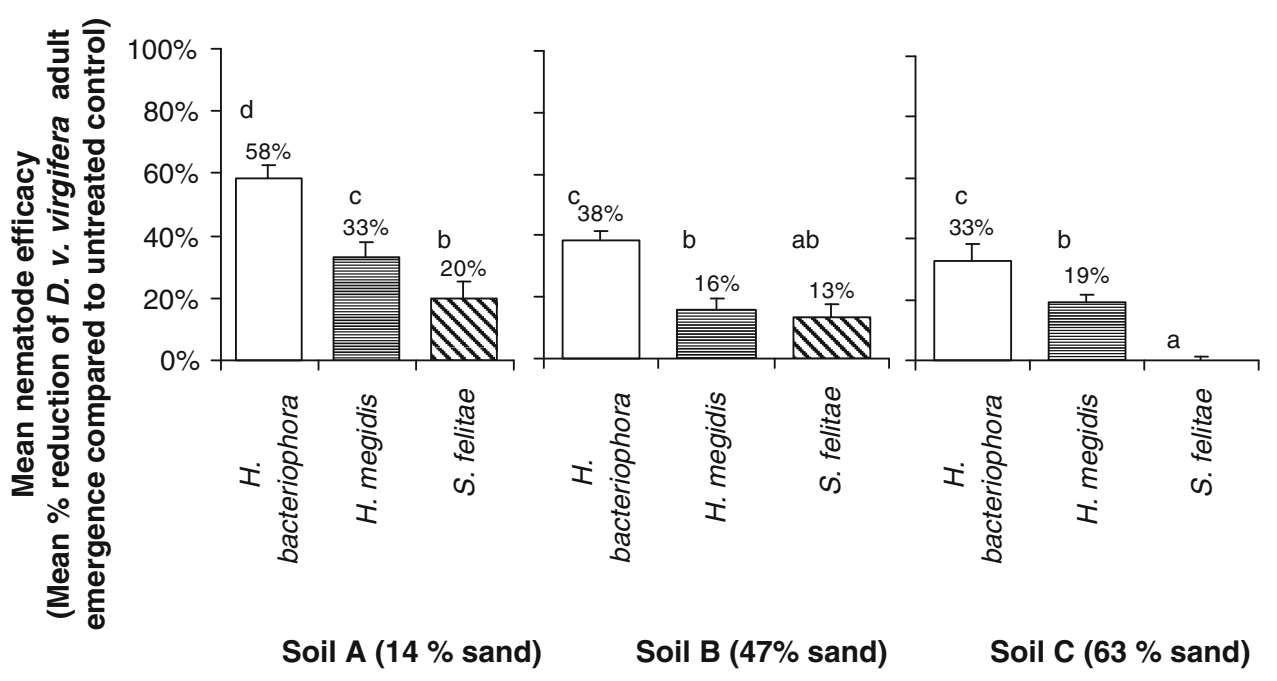

Fig. 2 Mean percent reduction of Diabrotica v. virgifera emergence due to applications of entomopathogenic nematodes into three different soils. Mean weighted reduction of adult emergence shown in comparison to the controls (=corrected efficacy); potted maize plants in a maize field in southern Hungary; soils were prepared by adding different amounts of river sand to natural gleyic Csernozem

factors might have prevented the nematodes from being more effective in the sandy soils.

One explanation for the apparently high efficacy of nematodes in non-sandy soils might be that the nematodes were applied too close to maize roots and $D$. v. virgifera (here $150 \mathrm{~mm}$ ) to detect a reduction in nematode movement in heavy soils with low sand content. It is known that movement of nematodes can be restricted in dense soils such as clay or silty clay; whereas, strong movement can usually be observed in loamy sand or sandy soil (Barbercheck and Kaya 1991; Barbercheck 1992; Portillo Aguilar et al. 1999; Boff and Gandin 1992). Alekseev et al. (2006) reported that the mobility of $S$. carpocapsae was greater in marine sand than in sandy loam soil, and Koppenhoefer and Fuzy (2006a) showed that the infectivity of $S$. scarabaei slightly declined from sandy soils to fine clay soils, whereas no such effects were reported for H. bacteriophora and $H$. zealandica. Despite the advantages of sandy soils, nematodes may still find their hosts easier in clay soils than in sandy soils when moving along cracks formed by plant roots or the host larvae. In sand, however, they will disperse more equally and the net-movement towards the host larvae may therefore be less directed.

Another possible explanation for our results is that the survival of $D$. v. virgifera larvae is usually high in heavy soils (Turpin and Peters 1971; Beckler et al. 2004), such as clay, and would therefore provide most host larvae for nematode attack and propagation. Gaugler (2002) reported that nematodes usually have an advantage over insecticides in that they propagate within the pests and thus can react to high pest densities. This was also suggested for $H$. megidis soil of silty clay texture (soil A) taken from the experimental field; 11-22 potted maize plants were allocated to every treatment and control group for each of four experiment repetitions; error bars = SEM; letters above bars indicate significant differences of efficacies between soils and between nematode species according to the Bonferroni post hoc test at $P<0.05$ following an ANOVA

when applied against $D$. v. virgifera in maize fields in the USA (I. Hiltpold 2008, personal communication). However, in our study, the time period required for nematode propagation (1-2-week period) would hardly be enough to infest more larvae because the applied larvae already started to pupate and emerge as adults (Toepfer and Kuhlmann 2006). Moreover, our results suggest that high sand content, in contrast to above mentioned papers, only slightly reduced $D$. v. virgifera survival, measured in the untreated controls. We found approximately $12 \%$ survival from late second instar to the adult stage in the silty clay with low sand content and $8 \%$ in the sandiest soil. However, the negative influences of sand to first instar larvae, such as through coarse texture or fast desiccation of sandy soils (Gustin and Schumacher 1989; Macdonald and Ellis 1990) were excluded in this study through the infestation of plants with later less sensitive instars. Such mortality factors of first instars might be the reason that greater damage from $D$. v. virgifera, particularly plant lodging, are more often reported from regions with heavy and dense soils than from regions with light sandy soils (I. Zseller, 2008, personal communication). Another reason might be that population pressure of $D . v$. virgifera is usually higher in regions with heavy and dense soils due to higher intensity of maize growing when compared to regions with sandy soils considered suboptimal for maize production due to soil aridity (I. Zseller, 2008, personal communication).

In conclusion, the efficacy data presented here suggest that nematodes might be suitable biological control agents for managing $D$. v. virgifera in most soils, including heavy non-sandy soils, such as those found in the intensive maize 
production areas of Central Europe. On average across soils, $H$. bacteriophora was more effective at controlling D. v. virgifera larvae $(43 \%)$ than $H$. megidis $(23 \%)$ and S. feltiae $(11 \%)$. This should encourage and support the development of a biological control product against this invasive alien maize pest in Europe.

Acknowledgements This work was possible due to the kind hospitality and technical support of the Plant Health and Soil Conservation Directorate of Csongrad County in Hodmezovasarhely in Hungary, offered by Ibolya Zseller, Jozsef Gavallier, Kataline Buzas, Erzsebet Dormannsne, Piroska Szabo, Andras Varga, Laszlo Hodi, and others. Many thanks to Ralf Udo Ehlers (University of Kiel, Germany), Arne Peters (e-nema GmbH, Schwentinental, Germany), and Erich Franck (Andermatt Biocontrol, Grossdietwil, Switzerland) for technical advice and providing the nematodes. We further like to thank Christina Pilz (Agroscope ART, Reckenholz, Switzerland) as well as the summer students Bobe Kovacs (Szentes, Hungary), Ferenc Koncz and Diana Gyongyosi (both Hodmezovasarhely, Hungary) for technical assistance and Wade Jenner (CABI Europe-Switzerland) as well as Michael Cripps (Lincoln University, New Zealand) for reviewing the manuscript. We acknowledge Agroscope ART, Reckenholz, Switzerland, for providing soil moisture data loggers. This study was mainly funded by the CTI Innovation and Technology Fund of Switzerland (CTI P-No. 7485.1 LSPP-LS), and supported by the COST 850 Action via a short term scientific mission.

Open Access This article is distributed under the terms of the Creative Commons Attribution Noncommercial License which permits any noncommercial use, distribution, and reproduction in any medium, provided the original author(s) and source are credited.

\section{References}

Alekseev E, Glazer I, Samish M (2006) Effect of soil texture and moisture on the activity of entomopathogenic nematodes against female Boophilus annulatus ticks. Biocontrol 51:507-518

Atterberg A (1905) Die rationelle klassifikation der sand und kiese. Chemiker Zeitung 29:195-198

Babendreier D, Keller S, Romeis J, Bigler F, Kuhlmann U, Toepfer S, Turlings T, Schaub L (2006) New approaches for controlling the western corn rootworm. Agrarforschung 13:80-83 (in German)

Barbercheck ME (1992) Effect of soil physical factors on biological control agents of soil insect pests. Fla Entomol 75:539-548

Barbercheck ME, Kaya HK (1991) Effect of host condition and soil texture on host finding by the entomogenous nematodes Heterorhabditis bacteriophora (Rhabditida: Heterorhabditidae) and Steinernema carpocapsae (Rhabditida: Steinernematidae). Environ Entomol 20:582-589

Barbercheck M, Wang J (1997) Insect host plant effects on the biology of entomopathogenic nematodes. In: Annual meeting of the society of invertebrate pathology, vol 30, p 3

Beckler AA, French BW, Chandler LD (2004) Characterization of western corn rootworm (Coleoptera: Chrysomelidae) population dynamics in relation to landscape attributes. Agric For Entomol 6:129-139

Boff MIC, Gandin CL (1992) Principal pests in the cultivation of watermelons and their control. Agropecuária Catarinense 5:39-41

Brust GE (1991) Augmentation of an endemic entomogenous nematode by agroecosystem manipulation for the control of a soil pest. Agric Ecosyst Environ 36:175-184
Cabanillas HE, Wright RJ, Vyas RV (2005) Cereal, fibre, oilseed and medicinal crop applications. In: Grewal PS, Ehlers RU, Shapiro DI (eds) Nematodes as biocontrol agents. CABI Publishing, Wallingford, UK, pp 265-280

Creighton CS, Fassuliotis G (1985) Heterorhabditis sp. (Nematoda: Heterorhabditidae): A nematode parasite isolated from the banded cucumber beetle, Diabrotica balteata. J Nematol 17:150-153

Ellsbury MM, Jackson JJ, Woodson WD, Beck DL, Stange KA (1996) Efficacy, application distribution, and concentration by stemflow of Steinernema carpocapsae (Rhabditida: Steinernematidae) suspensions applied with a lateral-move irrigation system for corn rootworm (Coleoptera: Chrysomelidae) control in maize. J Econ Entomol 85:2425-2432

Gaugler R (2002) Entomopathogenic nematology. CABI, Wallingford

Georgis R, Koppenhöfer AM, Lacey LA, Belair G, Duncan LW, Grewal PS, Samish M, Tan L, Torr P, van Toi RWHM (2006) Successes and failures in the use of parasitic nematodes for pest control. Biol Control 38:103-123

Gustin RD, Schumacher TE (1989) Relationship of some soil pore parameters to movement of first-instar western corn rootworm (Coleoptera: Chrysomelidae). Environ Entomol 18:343-346

Heimbach U, Rautmann D, Ganzelmeier H (2008) Influence of sowing technique of maize on drift of dust. IOBC IWGONEWSLETTER 29:18

IUSS working group (2007) World reference base for soil resources. World resource reports 103. FAO, Rome, p 115

Jackson JJ (1995) Pathogenicity of entomopathogenic nematodes for third instars of the western corn rootworm. J Nematol 27:504

Jackson JJ (1997) Field efficacy and ecology of three entomopathogenic nematodes with the western corn rootworm. J Nematol 29:586

Kaya HK (1990) Soil ecology. In: Gaugler R, Kaya HK (eds) Entomopathogenic nematodes in biological control. CRC Press, Boca Raton, pp 93-115

Kaya HK, Stock SP (1997) Techniques in insect nematology. In: Lacey LA (ed) Manual of techniques in insect pathology. Academic Press, London, pp 281-324

Kaya HK, Leong KLH, Burlando TM, Smith K, Yoshimura MA (1989) Entomogenous nematodes for biological control of the Western spotted cucumber beetle, Diabrotica undecimpunctata. J Nematol 21:568-569

Kinnear PR, Gray CD (2000) SPSS for windows made simple. Psychology Press Ltd, East Sussex

Kiss J, Edwards CR, Berger HK, Cate P, Cean M, Cheek S, Derron J, Festic H, Furlan L, Igrc-Barcic J, Ivanova I, Lammers W, Omelyuta V, Princzinger G, Reynaud P, Sivcev I, Sivicek P, Urek G, Vahala O (2005) Monitoring of western corn rootworm (Diabrotica virgifera virgifera LeConte) in Europe 1992-2003. In: Vidal S, Kuhlmann U, Edwards CR (eds) Western corn rootworm: ecology and management. CABI, Wallingford, pp 29-39

Koppenhöfer AM, Fuzy EM (2006a) Effect of soil type on infectivity and persistence of the entomopathogenic nematodes Steinernema scarabaei, Steinernema glaseri, Heterorhabditis zealandica, and Heterorhabditis bacteriophora. J Invertebr Pathol 92:11-22

Koppenhöfer AM, Fuzy EM (2006b) Nematodes for white grub control: effects of soil type and soil moisture on infectivity and persistence. USGA Turfgrass Environ Res Online 5:1-10

Krysan JL, Smith RF (1987) Systematics of the virgifera species group of Diabrotica (Coleoptera: Chrysomelidae: Galerucinae). Entomography 5:375-484

Kuhlmann U, Burgt WACM (1998) Possibilities for biological control of the western corn rootworm, Diabrotica virgifera virgifera LeConte, in Central Europe. Biocontrol News Inf 19:59-68 
Kung SP, Gaugler R, Kaya HK (1990) Soil type and entomopathogenic nematode persistence. J Invertebr Pathol 55:401-406

Kurtz B, Hiltpold I, Turlings T, Kuhlmann U, Toepfer S (2008) Comparison of the infectiousness of entomopathogenic nematodes among larval instars and pupae of the western corn rootworm. BioControl 54:255-265

Levine E, Oloumi SH (1991) Management of diabroticite rootworms in corn. Annu Rev Entomol 36:229-255

MacDonald PJ, Ellis CR (1990) Survival time of unfed, first-instar western corn rootworm (Coleoptera: Chrysomelidae) and the effects of soil type, moisture, and compaction on their mobility in soil. Environ Entomol 19:666-671

Miller N, Estoup A, Toepfer S, Bourguet D, Lapchin L, Derridj S, Kim KS, Reynaud P, Furlan L, Guillemaud T (2005) Multiple transatlantic introductions of the western corn rootworm. Science 310:992

Moeser J, Vidal S (2005) Nutritional resources used by the invasive maize pest Diabrotica virgifera virgifera in its new South-eastEuropean distribution range. Entomol Exp Appl 114:55-63

Pistorius J, Bischoff G (2008) Insecticidal seed treatments and honeybee poisoning incidents in Germany 2008-background and facts. IOBC IWGO-NEWSLETTER 29:18

Poinar GO, Evans JS, Schuster E (1983) Field test of the entomogenous nematode, Neoplectana carpocapsae. for control of corn rootworm larvae (Diabrotica sp., Coleoptera). Prot Ecol 5:337342

Portillo Aguilar C, Villani MG, Tauber MJ, Tauber CA, Nyrop JP (1999) Entomopathogenic nematode (Rhabditida: Heterorhabditidae and Steinernematidae) response to soil texture and bulk density. Environ Entomol 28:1021-1035

Rasmann S, Kollner TG, Degenhardt J, Hiltpold I, Toepfer S, Kuhlmann U, Gershenzon J, Turlings TCJ (2005) Recruitment of entomopathogenic nematodes by insect-damaged maize roots. Nature (London) 434:732-737

Reed JP, Hall FR, Taylor RAJ, Wilson HR (1991) Development of a corn rootworm larval threshold for Ohio. J Kansas Entomol Soc 64:60-68

Singh P, Moore RF (1985) Handbook of insect rearing. Elsevier, Amsterdam
Sivcev I, Tomasev I (2002) Distribution of Diabrotica virgifera virgifera LeConte in Serbia in 1998. Acta Phytopathol Entomol Hung 37:145-153

Smits PH, Wiegers GL, Vlug HJ (1994) Selection of insect parasitic nematodes for biological control of the garden chafer, Phyllopertha horticola. Entomol Exp Appl 70:77-82

Susurluk IA (2005) Establishment and persistence of the entomopathogenic nematodes, Steinernema feltiae and Heterorhabditis bacteriophora. $\mathrm{PhD}$ thesis, Christian Albrechts University of Kiel, Kiel, Germany.

Thurston GS, Yule WN (1990) Control of larval northern corn rootworm (Diabrotica barberi) with two steinernematid nematode species. J Nematol 22:127-131

Toepfer S, Kuhlmann U (2006) Constructing life-tables for the invasive maize pest Diabrotica virgifera virgifera (Col.; Chrysomelidae) in Europe. J Appl Entomol 130:193-205

Toepfer S, Gueldenzoph C, Ehlers RU, Kuhlmann U (2005) Screening of entomopathogenic nematodes for virulence against the invasive western corn rootworm, Diabrotica virgifera virgifera (Coleoptera: Chrysomelidae) in Europe. Bull Entomol Res 95:473-482

Toepfer S, Peters A, Ehlers R-U, Kuhlmann U (2008) Comparative assessment of the efficacy of entomopathogenic nematode species at reducing western corn rootworm larvae and root damage in maize. J Appl Entomol 132:337-348

Toepfer S, Hatala-Zseller I, Ehlers R-U, Peters A, Kuhlmann U (2010) Can the use of entomopathogenic nematodes reduce damage by western corn rootworm larvae? The effect of application techniques on field-scale efficacy. Agric For Entomol (in press)

Turpin FT, Peters DC (1971) Survival of corn rootworm larvae in relation to soil texture. J Econ Entomol 64:1448-1451

Ward DP, DeGooyer TA, Vaughn TT, Head GP, McKee MJ, Astwood JD, Pershing JC (2004) Genetically enhanced maize as a potential management option for corn rootworm: YieldGard rootworm maize case study. In: Vidal S, Kuhlmann U, Edwards CR (eds) Western corn rootworm: ecology and management. CABI, Wallingford, p 320 